\title{
O queer como gesto profano em João Gilberto Noll
}

\author{
Queer as a Profane Gesture in João Gilberto Noll \\ El queer como gesto profano en João Gilberto Noll
}

Evandro Sant'Anna*

\section{Resumo}

Partindo do princípio de que a escrita de João Gilberto Noll movimenta, em quase todo seu trajeto ficcional, deslocamentos de sentidos a respeito de categorias como "corpo", "sexo" e "gênero", apresentando seus personagens sempre através de uma ótica que coloca problemas aos limites binários "homem/mulher" e "homossexual/heterossexual", este artigo busca elaborar uma análise de Acenos e afagos (Noll, 2008c) e Berkeley em Bellagio (Noll, 2002) à luz do conceito denominado "profanação", proposto por Giorgio Agamben. Trata-se, neste trabalho, de compreender o queer inscrito na obra do autor gaúcho como uma potência que, contestando os territórios sobre os quais a própria literatura se assenta, é capaz de profanar os ditames discursivos administrados pela lógica biopolítica que sustenta o ordenamento contemporâneo.

Palavras-chave: queer, profanação, literatura brasileira contemporânea, João Gilberto Noll.

\begin{abstract}
Considering that João Gilberto Noll's writing animates, through almost all his fictional production, displacements of meanings regarding categories such as "body", "sex" and "gender", always presenting his characters from a perspective that challenges the binary limits "man/woman" and homosexual/heterosexual", this article seeks to elaborate an analysis of Acenos e afagos (Noll, 2008c) and Berkeley em Bellagio (Noll, 2002) in the light of the concept called "profanation," proposed by Giorgio Agamben. Here we understand the queer inscribed in the author's work as a power that, contesting the territories which literature itself is based on, is capable of profaning the discursive arbitrariness administered by the biopolitical logic that supports the contemporary arrangement.
\end{abstract}

Keywords: queer, profanation, Brazilian contemporary literature, João Gilberto Noll.

\begin{abstract}
Resumen
Noll mueve, en casi toda su trayectoria ficticia, desplazamientos de significados que se relacionan con categorías como "cuerpo", "sexo" y "género", presentando sus personajes desde una óptica que pone problemas a los límites binarios "hombre/mujer", "homosexual/heterosexual", este artículo propone la elaboración de un análisis de Acenos e afagos (Noll, 2008c) y Berkeley em Bellagio (Noll, 2002) a la luz del concepto llamado "profanación", propuesto por Giorgio Agamben. En este trabajo, se trata de entender el queer inscrito en la obra del autor como una potencia que, impugnando los territorios en los que se basa la literatura, es capaz de profanar los mandos discursivos administrados por la lógica biopolítica que sostiene el ordenamiento contemporáneo.
\end{abstract}

Palabras-clave: queer, profanación, literatura brasileña contemporánea, João Gilberto Noll.

\section{João Gilberto Noll e a escritura queer: um chamado profano}

É recorrente que, através dos tensionamentos narrativos responsáveis por nos indicar formas de enfrentamento a contextos de vulnerabilidade e violência, João Gilberto Noll coloque em evidência construções textuais que podem ser aproximadas do conceito denominado profanação. Encontramos, nas encenações deste exercício, corpos que traçam modos de vida que,

\footnotetext{
* Universidade Federal do Espírito Santo (UFES), Vitória, ES, Brasil. (Dorcid.org/0000-0002-4530-8768. E-mail: evandro.ramos.contato@gmail.com
} 
propagando ações de resistência, destacam possibilidades para a construção de uma abertura política deslocada dos ideais que modelam as noções de uma comunidade produtora do que Giorgio Agamben (2014) definira como vida nua. Os textos do autor, nesse sentido, não sugerem simplesmente, como fizera notar Edu Otsuka, a presença de uma "perda da noção de comunidade" (2001, p. 118); eles grifam, ao contrário, uma negação dessas noções, destacando uma escrita profana que sublinha a urgência política intrínseca à articulação de uma comunidade que vem, onde o vivente humano "não é nem há de ser ou realizar nenhuma essência, nenhuma vocação histórica ou espiritual, nenhum destino biológico" (Agamben, 2013, p. 45). Entram em cena, desse modo, produções textuais que, impulsionadas pelas potências de uma escritura queer estritamente profana, buscam promover justamente o oposto da vida nua, da vida que é incluída "na comunidade na forma da matabilidade" (Agamben, 2014, p. 84).

A aproximação que este artigo estabelece entre a produção de João Gilberto Noll e o pensamento agambeniano busca sugerir que a escritura queer, em seus gestos de desterritorialização - isto é, também, de "contestação" dos territórios (Dalcastagnè, 2012) sobre os quais a própria literatura se assenta -, coloca-nos diante de ressignificações éticas e estéticas que fissuram a cortina político-discursiva fabricadora das condições necessárias para que uma vida seja apreendida como "uma vida passível de luto" (Butler, 2018b, p. 42). Buscamos sugerir, então, que a escritura queer do autor gaúcho, apresentando-se como a extensão de "uma potência agenciadora de questionamentos à ordem estabelecida" (Soares, 2016, p. 10), ao se articular por meio de "uma linguagem que produz sujeitos que em suas precariedades gozam a existência" (Soares, 2016, p. 12), é capaz de profanar os enquadramentos epistemológicos que circundam nossos entendimentos acerca de categorias como "corpo", "sexualidade" e "gênero" - categorias que, por sua vez, podem determinar em que medida uma vida é ou não abandonada às armadilhas de morte gerenciadas pelo ordenamento político.

O que seria, contudo, profanar? De quais formas a profanação nos direciona a construção de um cotidiano que não dizime as singularidades dos sujeitos históricos? Buscando uma definição que contemple os dinamismos deste conceito - ou melhor, desta prática -, Giorgio Agamben retoma as contribuições dos juristas romanos e, analisando a dualidade presente entre as esferas do sagrado e do profano, afirma que "sagradas ou religiosas eram as coisas que de algum modo pertenciam aos deuses. Como tais, elas eram subtraídas ao livre uso e ao comércio dos homens" (Agamben, 2007, p. 65). Sagradas eram, nessa perspectiva, as coisas que, ao serem subtraídas ou retiradas do uso comum, tornavam-se inacessíveis aos seres viventes: não podiam ser consumidas, tocadas ou trocadas, não podiam servir como fonte de alimento ou gerar lucro, não podiam, consequentemente, circular pela esfera do livre uso. Dessa forma, enquanto consagrar (sacrare) era o ato que, através do sacrifício, marcava "a saída das coisas da esfera do direito humano, profanar, por sua vez, significava restituílas ao livre uso" daqueles que compunham o corpo social (Agamben, 2007, p. 65, grifo nosso). A profanação é, nesse sentido, o transporte do que antes fora separado à esfera sagrada de volta à esfera do livre uso.

O dispositivo responsável por fundamentar os limites da fronteira entre o sagrado e o profano é definido como religião. Analisando etimologicamente o termo, Agamben argumenta que este não deriva do religare - que liga e une o humano e o divino - , mas sim do relegere, "que indica a atitude de escrúpulo e de atenção que deve caracterizar as relações com os deuses, a inquieta hesitação (o 'reler') perante as formas [...] que se devem observar a fim de respeitar a separação" (Agamben, 2007, p. 66) entre a impossibilidade de uso e a liberdade perante o uso. Ou seja,

à religião não se opõem a incredulidade e a indiferença com relação ao divino, mas a "negligência", uma atitude livre e "distraída" [...] diante das coisas e do seu uso, diante das formas da separação e do seu significado. Profanar significa abrir a possibilidade de uma forma especial de negligência, que ignora a separação, ou melhor, faz dela um uso particular (Agamben, 2007, p. 66, grifo nosso).

Baseado em entrevista em que João Gilberto Noll (1997, p. 89) afirma que "o romance pode ser purificador porque o leitor vai entrar de uma maneira e sair de outra", Daniel da Silva (2006) aponta em sua dissertação de mestrado que há uma aproximação entre a escrita nolliana e um projeto estético-religioso não didático. Este projeto, para o crítico, fundamenta-se pelo intermédio 
único e exclusivo da linguagem proposta pelo autor. Silva destaca que o percurso ficcional nolliano pode ser lido como um "chamariz para a materialidade humana" e que, "fazendo disso uma religião - religare entre homem e cosmos, sem fundo dogmático - Noll quer [...] colocar este homem frente a frente com seus dejetos, colocá-lo diante de sua corporalidade, de sua evidência material" (Silva, 2006, p. 20). Tendo em vista, contudo, que o autor constrói uma ficção "bastante teatral, talvez litúrgica" (Noll, 1996), uma ficção onde é possível perceber um conjunto de formas, gestos e especificidades que a linguagem textual adota como instrumento para a organização do tecido narrativo, afirmamos em nossa leitura que a forma religiosa por meio da qual o autor gaúcho fundamenta sua narrativa não se apresenta, como expõe Daniel da Silva, apenas como um dispositivo de ligação - religare - entre "homem" e "cosmos". Propomos, aqui, uma leitura do texto nolliano que tem como ponto de partida uma atmosfera religiosa intrínseca ao relegere, mas não somente em sentido de manter separadas, no trajeto ficcional, o sagrado e o profano. O ponto nodal da atmosfera religiosa que o autor constrói está precisamente relacionado à obliteração da separação produzida pela religião. Essa obliteração se sustenta, por sua vez, mediante a reivindicação de um uso do corpo que se afasta de qualquer ordem compulsória vinculada ao sexo, gênero ou desejo, e caminha, assim, na direção de uma subversão a partir da qual o corpo é finalmente liberto.

Seguindo com a análise ancorada nos traços da presença de uma religião na escrita de João Gilberto Noll, cabe breve retomada das contribuições de Walter Benjamin. Em seu O capitalismo como religião (2013), o autor nos afirma que o capitalismo não deve ser visto unicamente como estrutura condicionada por um aparato religioso, como afirmou Weber, mas sim como "um fenômeno essencialmente religioso" (Benjamin, 2013, p. 21, grifo nosso). A partir dessa premissa, Benjamin coloca em evidência três pontos pertinentes para que seja possível pensar o capitalismo como uma estrutura religiosa. O primeiro ponto é definido pelo fato de que, nele, as coisas só alcançam um significado através de um culto que não possui nenhum dogma ou teologia: reina, então, no capitalismo, o mais consistente utilitarismo. Intimamente ligado ao primeiro ponto - onde o culto se propõe como questão nodal -, encontra-se a segunda característica do capitalismo como estrutura religiosa: a duração permanente do culto utilitário. Enfim, o filósofo argumenta que a produção de culpa é o terceiro elemento que nos permite identificar o capitalismo como um fenômeno religioso:

O capitalismo presumivelmente é o primeiro caso de culto não expiatório, mas culpabilizador. Nesse aspecto, tal sistema religioso é decorrente de um movimento monstruoso. Uma monstruosa consciência de culpa que não sabe como expiar lança mão do culto, não para expiar essa culpa, mas para torná-la universal, para martelá-la na consciência e, por fim e acima de tudo, envolver o próprio Deus nessa culpa, para que ele se interesse pela expiação [...] Nisto reside o aspecto historicamente inaudito do capitalismo: a religião não é mais reforma do ser, mas seu esfacelamento. Ela é a expansão do desespero ao estado religioso universal, do qual se esperaria a salvação (Benjamin, 2013, p. 22).

Trata-se, então, de concebermos o capitalismo como um fenômeno que, através das prerrogativas da prática governamental liberal "consumidora de liberdade" (Foucault, 2008, p. 86), ao transformar tudo em culto e produzir a culpa ininterrupta que causa o esfacelamento dos sujeitos, organiza religiosamente um funcionamento social que arquiteta as determinações sobre os modos de vida dos seres viventes. Desse modo, como fez notar Michel Foucault em A vontade de saber (2018), vale lembrar que é durante a fase inicial do capitalismo que surge a nova forma de poder controladora dos corpos dos viventes humanos: o biopoder. Este, por sua vez, pode ser visto como um dos sintomas da produção de culpa impulsionada pelo capitalismo como religião, visto que foram os incansáveis métodos de confissão de práticas consideradas culposas que trouxeram à tona uma scientia sexualis e, por consequência, um saber sobre os corpos, seus desejos e exercícios de vida (Foucault, 2018, p. 66). A incansável produção de culpa intrínseca ao capitalismo foi também, portanto, estrutura fundamental para a consolidação de uma biopolítica que, caracterizada pela "administração dos corpos e pela gestão calculista da vida" (Foucault, 2018, p. 150), tiraniza 
sistematicamente os corpos daqueles que se localizam à periferia dos preceitos de uma "tecnologia social heteronormativa" ${ }^{1}$

Podemos perceber que o capitalismo, em sua configuração religiosa - de culto utilitário e fabricação de culpa -, funda uma nova organização de controle, disciplinarização e higienização dos corpos que se apresentam de forma dissidente à norma disposta pelo status quo: a norma de produção, consumo e impossibilidade de vivência de singularidades. Ou seja, "a nova arte de governar formada no século XVIII, implica em seu cerne uma relação de produção/destruição" (Foucault, 2008, p. 87) vinculada às liberdades individuais. Permite-se um exercício de liberdade garantindo que se vivam os sujeitos responsáveis pelo funcionamento das engrenagens do capitalismo, aniquilando, por outro lado, qualquer corpo que fissure os mecanismos religiosos que possam garantir a operabilidade do ordenamento vigente.

Posto em evidência a disposição religiosa do capitalismo responsável por engendrar uma lógica de poder preocupada em gerir os corpos e, com isso, a vida dos sujeitos históricos - isto é, a convergência orgânica e inextricável entre capitalismo e biopolítica -, retornamos, agora, ao pensamento agambeniano. Em diálogo com Walter Benjamin e suas contribuições sobre as maneiras através das quais o capitalismo se apresenta, o filósofo italiano, refletindo sobre o dispositivo da religião e sua relação com a experiência da profanação, argumenta que o capitalismo

generaliza e absolutiza, em todo âmbito, a estrutura da separação que define a religião. Onde o sacrifício marcava a passagem do profano ao sagrado e do sagrado ao profano, está agora um único, multiforme e incessante processo de separação, que investe toda coisa, todo lugar, toda atividade humana (Agamben, 2007, p. 71).

Não se trata, portanto, de apreender o queer como gesto profano em João Gilberto Noll unicamente como um movimento que, através de metáforas ou alegorias, ressignifica certos elementos da religiosidade cristã, mesmo porque, quando destacamos a presença de uma religião na escrita nolliana, estamos ressaltando os mecanismos de separação - de impossibilidade de uso - que recaem sobre os corpos de seus personagens, castrando, assim, suas potencialidades mais particulares. Visto que a ação de profanar configura um ato que ignora ou faz da separação articulada pela religião um uso particular, expressando-se através de "um uso (ou melhor, de um reuso) totalmente incongruente do sagrado" (Agamben, 2007, p. 66), e, ainda, que o capitalismo é, em si, um fenômeno religioso, consideramos, como ponto central de nossa análise, que o queer como gesto profano se apresenta na restituição do que fora separado - ou melhor, sacralizado - pelo capitalismo e seus aparatos biopolíticos: os corpos, as sexualidades e os modos através das quais ela é exercida.

É preciso lembrar que o uso aberto pela ação profana é rigorosamente desvinculado do utilitarismo regulamentado pela religião capitalista. Trata-se de conceber o uso estendido pela profanação como uma "categoria política fundamental" (Agamben, 2017, p. 42) que elabora um percurso através do qual é possível se pensar um afastamento ligado às organizações políticas violentas e higienizadoras. Sob essa ótica, ao argumentarmos que o uso do corpo - seja em exercícios sexuais, de deslocamento, de proliferação de desejos etc. - apresenta-se, em João Gilberto Noll, como ação de resistência, estamos analisando sua escrita a partir de uma acepção em que usar o corpo indica uma "afeição que se recebe enquanto se está em relação com um ou mais corpos" (Agamben, 2017, p. 48), sem que essa afeição seja remediada pelas arbitrariedades fabricadas por engrenagens que mantêm operantes o motor biopolítico. As narrativas profanas acionadas pelo queer inscrito em Noll, então

Põem sob rasura a noção ontológica de sujeito, agenciam intensidades múltiplas e identificações subalternizadas, forjando corpos vagabundos antiprodutivos, anticapitalistas, bem como dão visibilidade a vivências precárias, que se encontram fora dos escopos de inteligibilidade de gêneros, sexo, desejo e práticas sexuais legitimados (Soares e Silva, 2018, p. 84).

\footnotetext{
${ }^{1}$ Em seu Manifesto contrassexual, o filósofo Paul B. Preciado sugere que a "tecnologia social heteronormativa" pode ser compreendida como um "conjunto de instituições tanto linguísticas como médicas ou domésticas que produzem constantemente corpos-homem e corpos-mulher" (Preciado, 2017, p. 28).
} 
Se a "literatura é gesto na medida em que fala" (Nancy, 2015, p. 99, tradução nossa) através de proposições escritas que ultrapassam os limites da mera descrição representativa para "inscrever potências de sentidos não dados, não disponíveis" (Nancy, 2015, p. 82, tradução nossa), nossa leitura apreende a escritura queer como a extensão de um gesto literário estritamente profano. Ao rasurar as repetições discursivas que alimentam práticas gestoras dos corpos e das formas-de-vida ${ }^{2}$ que os constituem - isto é, afastando-se do desejo de se ancorar, ou, ainda, de reproduzir as categorizações estanques relacionadas a eixos como "masculino", "feminino", "homem" ou "mulher" - , a escritura queer desloca sentidos sacralizados pelos processos de separação orquestrados pela religião capitalista e, consequentemente, permite "uma leitura desierarquizante e não normativa sobre sexo/gênero" (Maia, 2013, p. 222). É justamente, então, por intermédio de operações profanas, de operações que demandam usos não normativos aos mais variados corpos dentro do espaço literário, que podemos

reinscrever o conceito de escrituras queer a partir de uma noção de desterritorialização absoluta, ou seja, como uma escritura que rompe com o território existente e hegemônico da heteronormatividade e com as estabilidades dadas pela heterossexualidade compulsória. As escrituras queer compartilham a possibilidade de funcionar como textos de desterritorialização da heteronorma, e também da homonorma, sendo possíveis, nesse caso, de engendrar uma reterritorialização não somente a partir da multiplicidade, mas uma reterritorialização pela diferença não heterocentrada, através de um devir ruptura, de um devir não normativo, de um devir da criatividade e da multiplicidade dos corpos ao/para o infinito (Maia, 2013, p. 225).

A escritura queer, compreendida sob essa ótica como um gesto de escrita que, através da reivindicação de um uso do corpo deslocado dos vetores biopolíticos, resiste às violências discursivas que produzem nossas noções de "masculino" e "feminino", inaugurando, nos campos de um imaginário estritamente organizado pela tecnologia social heteronormativa, uma ética profana aberta à alteridade. Posicionando-se como produções "perturbadoras da normalidade, dos territórios hegemônicos e da heteronormatividade" (Maia, 2013, p. 231), o queer que encontramos nas narrativas de João Gilberto Noll é profano na medida em que desajusta - ou seja: retira o corpo da esfera da impossibilidade do uso - a "ordem linguística-sexual, cujo agenciamento encontra escapes aos processos de normalização sexual" (Soares, 2017, p. 161), como veremos adiante.

\section{O gesto profano em Berkeley em Bellagio e Acenos e afagos}

Embora as evidências do sujeito reduzido à vida nua sejam menos palpáveis em Berkeley em Bellagio (Noll, 2002) do que em romances como A fúria do corpo (Noll, 2008b), em que o ponto central da obra são as experiências de dois personagens - João Evangelista e Afrodite - que vagam pelas ruas de Copacabana tensionando os limites normativos comumente impostos ao corpo, é possível perceber que Berkeley em Bellagio apresenta seu personagem principal, desde o início da trama, através de situações de exclusão e vulnerabilidade. Tais situações, por sua vez, podem ser lidas como quesitos que justificam e, além disso, grifam a posição de recusa que estes personagens adotam em relação à subjetivação capitalista e seu controle minucioso dos corpos dos seres viventes. Berkeley em Bellagio, dessa forma, aciona movimentos de contraposição à gestão programada pelos dispositivos da religião capitalista que determina, violentamente, o que deve ou não se vincular à esfera do sagrado e à esfera do profano.

A narrativa tem como foco João, escritor gaúcho que termina um relacionamento estável com um homem e, buscando se desprender de quaisquer resquícios de memória individual ou coletiva, muda-se para Berkeley, na Califórnia, onde fora convidado a lecionar literatura e cultura brasileira. Articulada mediante a alternância da voz narrativa - apresentada em primeira e terceira pessoa -, a obra possibilita uma experiência de leitura que acompanha o

\footnotetext{
2 Podemos destacar, aqui, um dos aforismos da revista Tiqqun, que, tratando sobre a forma-de-vida, sugere que: "minha forma de vida não se relaciona a o que eu sou, mas como eu sou o que eu sou” (2001, p. 5, tradução nossa).
} 
desenvolvimento de seu protagonista a partir de uma perspectiva que ele mesmo constrói, aproximando enfaticamente o leitor das angústias e demais sensações que o constituem. Com esse recurso, a organização narrativa produz uma experiência de leitura que dinamiza as formas através das quais nos afetamos pelo texto e, portanto, pelas urgências políticas e sociais que ele ressalta. Sob essa ótica, ligamo-nos ainda mais, no sentido estrito de religare, aos usos melhor, aos reusos - que o protagonista abre, através do corpo, no percurso ficcional.

No romance, o narrador-personagem vive a todo o tempo atormentado pelo fato de não ter acesso a uma linguagem verbal e comunicativa que carregue potências capazes de posicioná-lo diante das possibilidades de construir novas relações - ou seja, acesso a uma linguagem verbal e comunicativa que lhe seja própria, que lhe assegure uma partilha de experiências com outros sujeitos. Contudo, notamos paulatinamente que João constrói, tendo o corpo como impulso produtor, caminhos que o direcionam ao outro, a novas significações de vida e, nesse sentido, ao escape da sensação de claustrofobia por estar "numa terra estranha sem falar a língua do lugar" (Noll, 2002, p. 11):

À primeira vista nada saía do lugar, ele próprio parecia estagnado desde que viera para um país do qual não falava a língua, mantendo uma distância gentil de seus alunos... Mas, ora, também eles com o inglês disponível e tudo que todos pareciam possuir em volta, ninguém no fundo dava a impressão de estar em gozo com a vida, aquela coisa que aquece: o tato no segredo de um outro, e este a relutar um pouco para ter em dobro logo mais... De súbito, descia-lhe então a ilusão de uma orgia intimista e conclusiva que o brindaria transportando-o para fora daquele campus, daquele país, do mundo até quem sabe (Noll, 2002, p. 12).

Fica evidente no trecho destacado a importância que João atribui ao corpo em seu uso sexual. Em meio ao estado de estagnação em que se encontra, sentindo-se avulso por se distanciar dos outros sujeitos, é através da imagem de uma "orgia intimista" que o protagonista parece ver uma abertura para algo novo. Lemos aqui o "intimista" em um sentido de intimidade - de uma esfera que permite ao narrador a fruição de seus sentimentos e vontades mais profundas. É possível notar, também, que João assume, nessa forma específica de imaginar o próprio corpo (em uma orgia que lhe propicie uma entrega afetuosa), um refúgio contra o não pertencimento que o assola e, consequentemente, um direcionamento às novas possibilidades que lhe assegurem o gozo de uma vida aquecida pelo "tato no segredo de um outro". Imaginar uma "orgia intimista" faz com que o personagem construa, dessa forma, a imagem de um corpo que se desloca de uma situação de exclusão a uma partilha de intimidade capaz de transgredir normas ou determinações sociais construídas por um espaço geográfico específico.

É preciso destacar, ainda, que as ações executadas pelos corpos apresentados em Berkeley em Bellagio fogem completamente à normatização estruturada pelos dispositivos biopolíticos. É possível ver na citação acima, por exemplo, a projeção de um exercício sexual afastado dos comportamentos aprovados pelas engrenagens morais arraigadas aos preceitos da religião capitalista. Ou seja, ao imaginar uma "orgia intimista", ação contrassexual que embaça os limites que moldam tanto as corporalidades, quanto seus exercícios - uma vez que desloca os sentidos normativos atribuídos a estas questões -, João expressa o desejo de um ato que pode profanar a lógica sexual vigente.

Percebemos também, logo no início do romance, que seus personagens não se enquadram em uma marcação de gênero ou sexualidade que corresponda às arbitrariedades cisheterocentradas e sua tirania binária, fazendo ruir constantemente as cristalizações conceituais que se ligam a tais elementos. Notamos, assim, que João experiencia relações sexuais com Maria. Esta, entretanto, é também construída por meio de um corpo dissidente, sendo apresentada como uma mulher que foge às prerrogativas que determinam o que é um corpo feminino. Cabe, aqui, retomada do seguinte trecho da narrativa:

Ela o masturbava sem avidez. Ele enfiava o dedo primeiro com suavidade pela vagina dela e encontrava lá no fundo um pênis em miniatura; quando chegava ali a coisa já o esperava em riste, e nela ele mexia como num pênis sem glande ou prepúcio, pura umidade que a promessa de seus dedos tinha o dom de excitar. Naquele ponto se banqueteavam, até que o seu próprio pau monstruosamente maior viesse a toda e entornasse o leite pelas coxas dela. Aliás, ele nunca 
conseguiu (nem procurou, por certo) uma única informação sobre essa peça do corpo feminino que bem longe estava do clítoris. Só Maria a possuía? Seria um quisto provedor de benefícios sem conta, o pau feminino primevo, simétrico aos mamilos masculinos que tanto prazer de carícias poderiam das a alguns homens? (Noll, 2002, p. 15, grifo nosso).

O romance sugere, nessa passagem, maneiras outras de existência e de constituição de experiências que ultrapassam a ótica de um corpo submetido às normas arraigadas ao ideal biopolítico; de um corpo que tem, arbitrariamente, suas contingências separadas para a esfera do não uso em nome da manutenção de uma matriz heterossexual. Assim, "um pênis em miniatura" que compõe, na narrativa, parte do corpo de uma mulher, apresenta-se como um elemento que profana os mecanismos de separação vinculados às noções de gênero e sexualidade elencadas no ordenamento contemporâneo. Vemos a desconformidade do corpo de Maria em Berkeley em Bellagio, portanto, como elemento que ressignifica os alvos sobre os quais recaem os dispositivos que higienizam as formas de vida que caminham na contramão da religião capitalista e seu modelamento de corpos. Tendo em vista as potências dessa ressignificação, cabe sublinhar agora algumas reflexões propostas por Paul B. Preciado em seu Manifesto contrassexual (2017). Para o filósofo,

o sistema sexo/gênero é um sistema de escritura. O corpo é um texto socialmente construído, um arquivo orgânico da história da humanidade como história da produçãoreprodução sexual, na qual certos códigos se naturalizam, outros ficam elípticos e outros são sistematicamente eliminados ou riscados. A (hetero)sexualidade, longe de surgir espontaneamente de cada corpo recém-nascido, deve se reinscrever ou se reinstruir através de operações constantes de repetição e recitação dos códigos (masculino e feminino) socialmente investidos como naturais (Preciado, 2017, p. 26).

Consideramos, sob essa ótica, o corpo como um texto que se constrói socialmente, apresentandose de forma orgânica de acordo com os códigos que o categorizam por meio de repetições normativas que incidem sobre ele. Berkeley em Bellagio - texto literário e, portanto, sistema de escritura que se organiza através de elementos codificados de forma estética - , ao encenar corpos desconformes, corpos contrassexuais, propõe a profanação das lógicas de escritura vinculadas tanto ao sistema literário - tendo em vista a ausência desses corpos no que se define como cânone - , quanto à construção do que seria um corpo feminino ou masculino.

Preciado destaca ainda que "o que é preciso fazer é sacudir as tecnologias da escritura do sexo e do gênero" e, assim, "modificar as posições de enunciação" (2017, p. 27) que essas escrituras carregam. Modificar essas posições pode ser visto como uma maneira de profanar os signos encadeados nos dispositivos de escritura. Nesse sentido, quando o leitor se depara com Maria, mulher descrita como alguém que possui "um pênis em miniatura", ele se depara com um signo transportado de uma esfera normativa - uma vez que esse pênis não se enquadra em um corpo lido como masculino - para uma esfera dissidente. Ou seja, se "a arquitetura do corpo é política" (Preciado, 2017, p. 31), a construção da narrativa nolliana propõe, numa inscrição de resistência, a arquitetura de corpos profanos; de corpos que abrem constantemente, no decorrer dos percursos ficcionais, possibilidades de usos deslocados da separação religiosa gerenciada pelo capitalismo.

É preciso colocar em destaque que não se trata, em nossa análise, de considerarmos o corpo de Maria como a marcação de uma transsexualidade ou intersexualidade, mas, sim, de uma leitura simbólica que o narrador nos permite fazer sobre o corpo dessa mulher: a potência profana em João Gilberto Noll, nesse caso, é justamente a presença de um corpo que, sem ultrapassar as visíveis barreiras de gênero e sexualidade, as implode com as formas através das quais coloca esse corpo em choque com outro corpo, evidenciando que

os órgãos que reconhecemos como naturalmente sexuais já são o produto de uma tecnologia sofisticada que prescreve o contexto em que os órgãos adquirem sua significação (relações sexuais) e de que se utilizam como propriedade, de acordo com sua "natureza" (relações heterossexuais) (Preciado, 2017, p. 31). 
Em Acenos e afagos (2008c), romance publicado seis anos após Berkeley em Bellagio, é possível notar também a articulação de um jogo que desloca e instaura outras dimensões acerca dos significados responsáveis por marcar o que seria um corpo feminino ou masculino. Além disso, a narrativa reestrutura as formas através das quais essas marcações se relacionam às expressões de desejo e sexualidade. Bem próximo do que propusera em A céu aberto (2008), na passagem em que o irmão do protagonista tem seu corpo completamente transformado, materializandose, na narrativa, em um corpo lido como feminino, João Gilberto Noll desenvolve, em Acenos $e$ Afagos (2008c), uma escrita que contesta ainda mais as posições de enunciação definidoras do que seria um corpo subordinado aos controles binários de gênero.

Na segunda metade do romance, o narrador-personagem, de nome João Imaculado, percebe que "os pontos cardeais" de sua "genitália" (Noll, 2008c, p. 143) já não lhe entregavam mais o que antes estava acostumado a encontrar: ou seja, o protagonista se depara com a ausência do órgão sexual que, na perspectiva da matriz heterossexual, responsabiliza-se por categorizá-lo como homem - "pau e saco". Ainda assim, experienciando uma espécie de metamorfose corporal, com a sensação de que nascia em seu corpo "um hímen a partir de uma base genital ainda incipiente", o narrador se dá por resignado e, enfim, entrega-se completamente à situação, que "não se mostrava de todo ruim" (Noll, 2008c, p. 143). É bastante significativo que a escrita instaure a imagem de um "hímen", parte sem finalidades biológicas que compõe o corpo feminino, mas que, ao mesmo tempo, é tão cara à economia cristã-capitalista. Desse modo, a profanação, aqui, relaciona-se também ao nome do protagonista, "João Imaculado": este, ironicamente, macula não só uma arquitetura corporal que antes o compunha, mas o próprio "hímen" que nasce em seu corpo e, o mais importante, as fronteiras que comumente separam o que é masculino e feminino. Nesse sentido, o personagem nos narra:

[...] pensei, sim, a respeito do momento, pensei que o engenheiro estaria com o órgão genital agora em condições, enquanto eu, eu ficaria sem cacete. Não que já tivesse uma vagina, mas na região pélvica um certo rumor côncavo se fazia ouvir, lembrava uma caldeira preparando a solução para meu novo foco de deleite, alguma coisa como um chamamento noturno, subterrâneo, embora ainda até certo ponto indeciso. Me sentia em transição. Não era mais homem sem me encarnar no papel de mulher. Eu flutuava sem o peso das determinações (Noll, 2008c, p. 145, grifo nosso).

É curioso - e importante - perceber que a experiência do personagem inaugura uma arquitetura corporal limítrofe. Os signos que carregam as marcações compulsórias vinculadas às possibilidades de leitura sobre seu corpo se entroncam: "não era mais homem sem me encarnar no papel da mulher", afirma o narrador. Contudo, essas marcações se confundem em um limiar que dificulta a cristalização do corpo do personagem sob a égide de conceitos tão fechados quanto as noções de "masculino" e "feminino", bem como as de "homem" ou "mulher". João Imaculado, "sem cacete", mas, ao mesmo tempo, sem "vagina", encontrando "na região pélvica um certo rumor côncavo", abre passagem para a solidificação de uma forma de vida estritamente deslocada dos processos de higienização intrínsecos ao ordenamento político contemporâneo.

Não se trata, portanto, de lermos João Imaculado, como parecem afirmar Michele Jimenez e Regina Silva (2010), em artigo sobre o romance, como alguém que possui um conflito ou crise de identidade "vinculada a sua orientação sexual, dividida entre a heterossexualidade e a homossexualidade" (2010, p. 33) - alguém que, além disso, prende-se a uma masculinidade problemática gerenciada pelo medo de se enxergar distante dos preceitos da sociedade heterocentrada. Sabemos, como nos destaca o narrador ainda no início da obra, que ele "queria foder com todos os homens do mundo e com meia dúzia de mulheres" (Noll, 2008c, p. 18). Tal afirmação, antes de assinalar qualquer estado conflituoso, grifa o fato de que o personagem se impõe no romance de maneira que beira a indiferença às ideias solidificadas que recaem sobre seu corpo e seu desejo; mesmo porque, como é possível notar, João Imaculado "flutuava sem o peso das determinações" (Noll, 2008c, p. 145). 
A partir desses apontamentos, podemos nos aproximar de algumas das proposições expostas por Judith Butler em seu Problemas de gênero (2018a). Dialogando com Monique Wittig, a filósofa afirma que

o poder da linguagem de atuar sobre os corpos é tanto causa da opressão sexual como caminho para ir além dela. A linguagem não funciona de forma mágica nem inexorável [...] Ela pressupõe e altera seu poder de ação sobre o real por meio de atos elocutivos que, repetidos, tornam-se práticas consolidadas e, finalmente, instituições. A estrutura assimétrica da linguagem, que identifica com o masculino o sujeito que representa e fala como universal, e que identifica o falante do sexo feminino como "particular" e "interessado", absolutamente não é intrínseca a línguas particulares ou à linguagem ela mesma. Não podemos achar que essas posições assimétricas decorram da "natureza" dos homens e das mulheres, pois, como estabeleceu Beauvoir, tal "natureza" não existe (Butler, 2018a, p. 202).

O queer nolliano, proposto a partir de Maria, em Berkeley em Bellagio, e João Imaculado, em Acenos e afagos, aponta-nos corpos que ocupam um entrelugar, corpos que não se encaixam no binarismo programado pela matriz heterossexual, corpos que flutuam sem o peso de quaisquer determinações engessadas. Os personagens do autor costuram, com suas morfologias corporais subversivas, nos percursos dos tecidos narrativos, a inauguração de existências outras: a insurgência de formas de vida que movimentam constantemente potências para novos usos. Considerando a literatura como uma "distância aberta no interior da linguagem [...] uma espécie de linguagem que oscila sobre si mesma" e se organiza como a extensão de "um ritual prévio que traça o espaço da consagração das palavras" (Foucault, 2000, p. 142), a escritura queer de João Gilberto Noll instaura, num gesto profano perante as marcações que definem como instituição questões como gênero e sexualidade, uma literatura que, em seu interior, em seu processo de consagração das palavras - isto é, de separação, de escolha, de proposição ética e estética - , faz cair por terra a ideia de uma natureza humana a partir da qual os seres viventes devem se moldar. Trata-se, portanto, de uma literatura que, através de uma linguagem deslocada das repetições que sedimentam gênero e sexualidade, propondo personagens que expressam formas de vida singulares, contrapõe-se às organizações contemporâneas que buscam, incessantemente, sacralizar corpos - separá-los à esfera do não uso - subversivos.

Entram em destaque na literatura produzida por João Gilberto Noll, nesse sentido, sujeitos que profanam a ideia do corpo como um território estático que, consagrado pela religião capitalista, fundamenta-se através da matriz assentada sobre os binarismos homem/mulher, masculino/feminino, homossexual/heterossexual. Pensando o território como "sinônimo de apropriação, de subjetivação fechada sobre si mesma” (Guattari e Rolnik, 1986, p. 323) em consonância com o fato de a escrita nolliana divergir das marcações constantemente ligadas ao corpo, notamos que os personagens construídos pelo autor se movimentam num impulso que desterritorializa seus espaços corporais e as extensões de suas práticas e desejos. Essa desterritorialização do corpo, em Noll, permite que seus personagens resistam "aos processos do tornar-se 'normal'" (Preciado, 2011, p. 14), indicando, assim, um afastamento "dos discursos da medicina anatômica e da pornografia [...] que constituíram o corpo straight e o corpo desviante moderno" (Preciado, 2011, p. 16).

Ainda em Acenos e afagos (2008c), João Imaculado narra:

$\mathrm{O}$ engenheiro pesava inerme sobre mim. Coloquei de novo, com esforço, a mão no meu púbis, e essa inspeção confirmava. Eu tinha uma conformação minuciosamente matizada na pélvis. De fato, ali tudo parecia aquoso, indefinido, sofrendo ainda de uma dolorida condição fabril [...] Entre o meu corpo e o dele havia minha mão começando a querer excitar aquilo que em mim ainda não era um campo estabelecido, mas um solo líquido, de permanente experimentação [...] Eu lambuzava os dedos pela recente fenda do meu sexo ainda em devir, sem qualquer norte conclusivo. Começava a gostar daquela manipulação no canteiro de obras entre as minhas pernas (Noll, 2008c, p. 146, grifo nosso).

A cena em destaque dialoga estreitamente com o propósito que o autor gaúcho carrega ao tentar "tratar da alma humana, essa coisa fluída, flutuante, às vezes até demencial" (Noll, 2009), aglutinando, inclusive, tais questões às formas através das quais os corpos de seus personagens 
são constituídos. É sintomático que, ao propor, como sugerimos, corpos em processo de desterritorialização, a escrita nolliana aproxime a metamorfose corporal que João Imaculado experiencia à imagem de algo líquido. Definindo o órgão que começava a brotar em sua região genital como um membro "aquoso", o narrador coloca em evidência o constante processo de mutação intrínseco ao seu corpo. Desse modo, assim como as águas de um rio, o corpo do protagonista de Acenos e afagos (2008c) corre pelo desenrolar da narrativa criando sulcos nos terrenos responsáveis pelo firmamento de uma existência meramente biológica. Assumindo seu sexo como o processo de um "devir", encarando seu corpo como um canteiro de obras e, portanto, como algo não finalizado, João Imaculado evidencia o fato de que "um corpo não tem antes nem depois" (Nancy, 2000, p. 95), constituindo-se como singularidade fincada na "permanente experimentação [...] sem qualquer norte conclusivo" (Noll, 2008c, p. 146).

Além disso, analisando o romance Berkeley em Bellagio, é possível notar que o corpo profano como exercício político configura-se também através da constante de que os sujeitos que sofrem "choques insulínicos" como forma de punição às suas sexualidades vistas como um perigo em relação às "metas proliferantes da espécie" (Noll, 2002, p. 22) - tão bem regulamentadas pelos dispositivos biopolíticos - são os mesmos que, num impulso de resistência e criação, rearticulam os limites cristãos, morais e normativos impostos pelo capitalismo como religião. Nota-se:

Raro é esse ragazzo para quem ele olha agora e diz: sim, Deus baixou aqui, é vivo. De imediato tocou na espádua arcaica do peninsular divino, mesmo que o ragazzo não soubesse, não importa, era Deus que ele continha no seu peito arfante, não o Deus que não saía das igrejas mas o Deus que pulsava atrás da calça apertada do ragazzo, o Deus que se aplumava e se punha rígido, colosso! (Noll, 2002, p. 29).

É possível perceber que, além de profanar a lógica heteronormativa impulsionada e mantida pelos mecanismos higienizadores das sociedades contemporâneas, ao consumar um ato sexual na contramão do que fora estipulado como padrão pelas engrenagens biopolíticas, João ressignifica também alguns elementos atribuídos à religiosidade cristã - na citação acima, ressignifica o próprio Deus. Percebe-se, aqui, uma dupla profanação: por um lado, restitui-se o exercício de uma sexualidade proibida ao uso comum; por outro, reelabora-se um dispositivo religioso de forma transgressora e, sob a ótica da norma, imoral:

O Deus que foi levado pelo escritor porto-alegrense para atrás de uma cortina malcheirosa pelo tempo, o Deus que ali se deixou ordenhar como um bovino e que ali se deixou beber não bem em vinho mas em leite que o nosso senhor gaúcho engoliu aos poucos, na carestia da idade, lembrando-se da Primeira Comunhão, terço nas mãos, ar de bem-aventurança (Noll, 2002, p. 29).

A analogia que emparelha o órgão sexual masculino a "Deus" e, para além disso, encena o sexo oral com a imagem do rito eucarístico cristão, evidencia o que Agamben (2007, p. 66) dissera a respeito do uso incongruente do sagrado, de um uso desvinculado do utilitarismo. Dessa forma, a narrativa subverte os preceitos de práticas sexuais normativas direcionando seu personagem principal às possibilidades de ressignificação dos dispositivos que fundamentam as violências por ele vividas. Ademais, na mesma medida em que João aproxima os elementos religiosos da esfera profana, ele encaminha o ato sexual a uma esfera santificada, construindo, consequentemente, uma reversão - ou uma reconstrução - da moral vigente.

Na religiosidade cristã, o rito eucarístico expressa a celebração da morte e ressurreição de Jesus Cristo. No processo litúrgico denominado comunhão, ação que representa a última ceia de Jesus com seus discípulos, após consagrados o pão e vinho - elementos que remetem respectivamente ao corpo e o sangue do filho de deus - , a eucaristia se torna a experiência mais importante da vida cristã, reunindo e fazendo da igreja o próprio corpo de Cristo. É significativo, portanto, que Noll tenha evidenciado em sua narrativa a profanação do que seria um dos sacramentos mais importantes para o cristianismo: o elemento que une os mais diversos sujeitos que se organizam em torno de uma única religiosidade, dando corpo à Igreja.

Quando João, na "carestia da idade" - e, aqui, sublinhamos o forte jogo de palavras estabelecido entre "carestia" e "eucaristia" - , ordenha o Ragazzo como um bovino e recebe dele 
o "leite" do "peninsular divino", ele joga tanto com elementos sexuais, quanto religiosos. Nesse sentido, o personagem restitui ao uso comum tanto o livre exercício de uma sexualidade dissidente, quanto o que se constitui como divino para a religiosidade cristã - no caso, o sangue de Cristo, transubstanciado, no texto ficcional, em "leite". Agamben destaca, ainda em seu "Elogio da profanação", que as esferas do sagrado e do jogo estão estreitamente vinculadas. Para ele, "a maioria dos jogos que conhecemos deriva de antigas cerimônias sacras, de rituais e de práticas divinatórias que outrora pertenciam à esfera religiosa em sentido amplo" (Agamben, 2007, p. 66). Assim, refletindo sobre o jogo como mecanismo da profanação, o filósofo italiano ressalta, ao retomar as contribuições de Émile Benveniste, que:

A potência do ato sagrado - escreve ele - reside na conjunção do mito que narra a história com o rito que a reproduz e a põe em cena. O jogo quebra essa unidade: como ludus, ou jogo de ação, faz desaparecer o mito e conserva o rito; como jocus, ou jogo de palavras, ele cancela o rito e deixa sobreviver o mito. "Se o sagrado pode ser definido através da unidade consubstancial entre o mito e o rito, poderíamos dizer que há jogo quando apenas metade da operação sagrada é realizada, traduzindo só o mito em palavras e só o rito em ações" (Agamben, 2007, p. 67).

Percebemos, na cena extraída de Berkeley em Bellagio, que João quebra a unidade do sagrado ao configurar, em sua organização textual litúrgica, tanto o ludus - uma vez que destitui os significados originais da eucaristia, conservando apenas o processo litúrgico da comunhão -, quanto o jocus - uma vez que, através do jogo de palavras com a utilização de "espádua arcaica do peninsular divino", "beber não bem em vinho mas em leite" e "Primeira Comunhão", remete-nos ao processo eucarístico, destacando-o, assim, sob a potência de novos significados.

A escritura queer de João Gilberto Noll é protagonizada, portanto, por uma espécie de redenção; não uma redenção entendida como "um evento no qual o que era profano se torna sagrado e o que tinha sido perdido é reencontrado", mas uma redenção que reivindica "a definitiva profanidade do profano" (Agamben, 2013, p. 95). Pensamos que, ao expor corpos não conformes que assumem ações sexuais fundamentalmente afastadas do que fora estabelecido como regra - ou, melhor, que retomam o uso de algo separado da esfera comum -, Berkeley em Bellagio e Acenos e afagos, com toda sua força literária, colocam em destaque uma rota de escape que desponta em novas possibilidades para o exercício de uma vida plena, de uma vida que pode ser definida como "a sinergia coletiva, [...] inteligência, afeto, cooperação, desejo" (Pelbart, 2003, p. 24). Assim, a escrita nolliana, mediante seu "devir-outro da língua" (Deleuze, 2011, p. 16), - mediante um devir-outro que não se submete às separações fundamentadas pela religião capitalista -, colocando-nos em íntimo contato com alteridades que reconstroem a todo instante os significados do que as insere em situações de violência e vulnerabilidade, carrega uma potência que abre caminhos à profanação das estruturas de poder que embasam as relações contemporâneas e as formas através das quais ocupamos a realidade. Dessa maneira, o projeto ficcional nolliano, ancorado em enredos e personagens que assumem ações profanas, propõe "a criação de um povo que falta" (Deleuze, 2011, p. 14), de um povo que, embora seja violentado única e exclusivamente por assumir, a partir do corpo, usos sistematicamente podados pela gestão biopolítica, resiste e propaga novas formas de vida.

O trajeto ficcional nolliano, desse modo, muito além de simplesmente expressar "o desamparo do sujeito integrante do contexto líquido-moderno" (Reis, 2017, p. 40), evidencia muita propositividade em relação a "um desejo de comunidade e criação (e, ainda, manutenção) de laços afetivos" (Scardino, 2015, p. 121) que escapam ao que fora moldado pelos dispositivos biopolíticos. Nesse sentido, indicamos em nossa leitura que a profanação do corpo no projeto nolliano aponta para uma ação política proposta por seus personagens: uma ação que separa o corpo de um uso utilitário intrínseco às estruturas do capitalismo como religião e o direciona ao livre uso de seus prazeres, permitindo que ele se ressignifique paulatinamente. Tais questões aproximam não só Berkeley em Bellagio e Acenos e afagos, mas boa parte do projeto ficcional do autor, da imagem proposta por Didi-Huberman (2014) acerca dos "vaga-lumes" que sobrevivem em meio às dificuldades de existência e, por poucos instantes, contaminam o ambiente com seus feixes de luz. João Gilberto Noll indica, nesses instantes ficcionais profanos, "modos de organizar - isto é, também, de desmontar, de analisar, de contestar - o próprio 
horizonte de nosso pessimismo" (Didi-Huberman, 2014, p. 118), impulsionando-nos, dessa forma, à construção de formas de vida que propaguem novas noções de comunidade.

\section{Referências}

AGAMBEN, Giorgio (2007). Profanações. Tradução de Selvino J. Assman. São Paulo: Boitempo.

AGAMBEN, Giorgio (2013). A comunidade que vem. Tradução de Cláudio Oliveira. Belo Horizonte: Autêntica.

AGAMBEN, Giorgio (2014). Homo sacer: o poder soberano e a vida nua I. Tradução de Henrique Burigo. Belo Horizonte: UFMG.

AGAMBEN, Giorgio (2017). O uso dos corpos. Tradução de Selvino J. Assmann. São Paulo: Boitempo.

BENJAMIN, Walter (2013). O capitalismo como religião. Tradução de Nélio Schneider e Renato Ribeiro Pompeu. São Paulo: Boitempo.

BUTLER, Judith (2018a). Problemas de gênero: feminismo e subversão da identidade. Tradução de Renato Aguiar. 16. ed. Rio de Janeiro: Civilização Brasileira.

BUTLER, Judith (2018b). Quadros de guerra: quando a vida é passível de luto. Tradução de Sérgio Lamarão e Arnaldo Marques da Cunha. Rio de Janeiro: Civilização Brasileira.

DALCASTAGNÈ, Regina (2012). Literatura brasileira contemporânea: um território contestado. Vinhedo: Horizonte.

DELEUZE, Gilles (2011). Crítica e clínica. Tradução de Peter Pál Pelbart. São Paulo: Editora 34.

DIDI-HUBERMAN, Georges (2014). Sobrevivência dos vaga-lumes. Tradução de Vera Casa Nova; Márcia Arbex. Belo Horizonte: Editora UFMG.

FOUCAULT, Michel (2000). "Linguagem e literatura” In. MACHADO, Roberto. Foucault, a filosofia e a literatura. Rio de Janeiro: Jorge Zahar Editor.

FOUCAULT, Michel (2008). Nascimento da biopolítica: curso dado no Collège de France (1978-1974). Tradução de Eduardo Brandão. São Paulo: Martins Fontes.

FOUCAULT, Michel (2018). História da sexualidade I: a vontade de saber. Rio de Janeiro; São Paulo: Paz e Terra.

GUATTARI, Félix; ROLNIK, Suely (1996). Micropolítica: cartografias do desejo. Petrópolis: Vozes.

JIMENEZ, Michele; SILVA, Regina (2010). Sexualidade e identidades conflitantes em Acenos e Afagos, de João Gilberto Noll. Terra Roxa e Outras Terras, v. 18, p. 26-37.

MAIA, Helder Thiago Cordeiro (2013). Constelações queer ou por uma escritura da diferença. In. COLLING, Leandro; THÜRLER, Djalma (Org.). Estudos e políticas do CUS: Grupo de pesquisa Cultura e Sexualidade. Salvador: EDUFBA. p. 219-237.

NANCY, Jean-Luc (2000). Corpus. Tradução de Tomás Maia. Lisboa: Veja, Limitada.

NANCY, Jean-Luc (2015). Demande: littérature et philosophie. Paris: Éditions Galilée.

NOLL, João Gilberto (1996). Entrevista para Copo de mar. Disponível em: http://www.joaogilbertonoll.com.br/entrevistas.html. Acesso em: 12 jan. 2019.

NOLL, João Gilberto (1997). João Gilberto Noll: o tempo da cigarra.[Entrevista cedida a] José Weis. Brasil/Brazil, Pontifícia Universidade Católica do Rio Grande do Sul, p. 78-94.

NOLL, João Gilberto (2002). Berkeley em Bellagio. Rio de Janeiro: Objetiva.

NOLL, João Gilberto (2008a). A céu aberto. Rio de Janeiro: Record.

NOLL, João Gilberto (2008b). A fúria do corpo. Rio de Janeiro: Record.

NOLL, João Gilberto (2008c). Acenos e afagos. Rio de Janeiro: Record.

NOLL, João Gilberto (2009). Entrevista a Entrelinhas. Disponível em: https:/ / www.youtube.com/watch?v=qg0iYD8holg\&feature=related. Acesso em 11/02/2019. 
OTSUKA, Edu (2001). Marcas da catástrofe: experiência urbana e indústria cultural em Rubem Fonseca, João Gilberto Noll e Chico Buarque. São Paulo: Nankin.

PELBART, Peter Pal (2003). Vida Capital: ensaio de biopolítica. São Paulo: Iluminuras.

PRECIADO, Paul B (2011). Multidões queer: notas para uma política dos "anormais". Revista de Estudos Feministas, v. 19, n. 1, p. 11-20.

PRECIADO, Paul B. (2017). Manifesto contrassexual. Tradução de Maria Paula Gurgel Ribeiro. São Paulo: n-1 edições.

REIS, Gleiciane (2017). Identidade à deriva: uma leitura de Berkeley em Bellagio, de João Gilberto Noll. Revista Prâksis, v. 2, p. 39-50.

SCARDINO, Rafaela (2015). Ética do afeto, prática de comunidade: a partir de João Gilberto Noll. Revista Landa. v. 3, n. 2, p. 116-128.

SILVA, Daniel (2006). Reinvenções da precariedade: o sujeito e o corpo na obra de João Gilberto Noll. Dissertação. (Mestrado em Letras) - Pontifícia Universidade Católica do Rio de Janeiro, Rio de Janeiro.

SOARES, Mayana (2016). Feitiçarias, terrorismos e vagabundagens: a escritura queer de João Gilberto Noll. Dissertação (Mestrado em Letras) - Universidade do Estado da Bahia, Salvador.

SOARES, Mayana (2017). Processos de descolonização na literatura de João Gilberto Noll: transgressões no sexo e na língua. Revista Língua e Literatura, v. 19, n. 33, p. 146-164.

SOARES, Mayana; SILVA, Márcia (2018). A escritura queer de João Gilberto Noll invade o mercado editorial brasileiro. Revista Entrelaces, v. 1, n. 13, p. 82-97.

TIQQUN (2001). Organe de liaison au sein du Parti Imaginaire: zone d'opacité offensive. Paris: Les Belles-Lettres. 